УДК 374.73; 004.418

Тукало Сергій Миколайович

аспірант

Інститут інформаційних технологій і засобів навчання НАПН України, м. Київ, Україна

kolobox@bigmir.net

\title{
ОРГАНІЗАЦІЙНО-ПЕДАГОГІЧНІ ЗАСАДИ ВПРОВАДЖЕННЯ ЕЛЕКТРОННОГО ДОКУМЕНТООБІГУ В НАУКОВИХ УСТАНОВАХ
}

\begin{abstract}
Анотація. Розглядається проблема впровадження системи електронного документообігу (СЕД) в наукових установах як чинник електронного урядування в Україні. Висвітлено особливості впровадження СЕД в держаних наукових установах. Виокремлено два аспекти впровадження: впровадження електронного документообігу як інформаційної системи та формування готовності користувачів до впровадження як педагогічний процес, організований на рівні неформальної освіти дорослих. Описано організаційно-педагогічні засади впровадження у вигляді організаційного забезпечення та організаційно-педагогічних умов готовності користувачів до впровадження. Подано розроблену автором організаційнопедагогічну модель впровадження СЕД. Типову модель життєвого циклу СЕД доповнено організаційно-педагогічною моделлю впровадження.
\end{abstract}

Ключові слова: система електронного документообігу; життєвий цикл; розробник; користувач; організаційно-педагогічні умови; модель; неформальна освіта.

\section{1. ВСТУП}

Побудова інформаційного суспільства є стратегічною метою провідних держав світу - США, Японії, Канади, а також країн - членів Свропейського Союзу. Розуміючи актуальність та важливість розвитку інформаційно-технічної сфери як запоруки конкурентоспроможності, все більше країн обирають аналогічну стратегію, зокрема й Україна.

Чинними нормативно-правовими актами у сфері розвитку інформаційного суспільства в Україні сформовано засади регулювання відносин щодо створення інформаційних електронних ресурсів, захисту прав інтелектуальної власності на інформаційні електронні ресурси, гарантій та механізмів доступу до публічної та суспільно необхідної інформації, упровадження систем електронного урядування, упровадження електронного документообігу, захисту інформації [17]. Передусім це Закони України: Про Концепцію Національної програми інформатизації, Про Національну програму інформатизації, Про Основні засади розвитку інформаційного суспільства України на 2007-2015 роки, Про електронні документи та електронний документообіг, Про захист персональних даних, Про доступ до публічної інформації. 3 2003 року на Національну програму інформатизації [14] щорічно спрямовуються сотні тисяч бюджетних гривень. За даними Держінформнауки в 2011-2012 роках на цю програму було витрачено 900 тисяч гривень (100 тисяч доларів США).

В інформаційному суспільстві зростає навантаження на уряд, що примушує його ефективніше виконувати свої функції за допомогою електронного уряду. Електронний уряд не є доповненням або аналогом традиційного уряду, а лише визначає новий спосіб взаємодії на основі активного використання інформаційно-комунікаційних технологій 3 метою підвищення ефективності надання державних послуг. Створення електронного уряду передбачає побудову загальнодержавної розподіленої системи громадського управління, що реалізує вирішення повного спектру завдань, пов'язаних з управлінням документами і процесами їх обробки. Отже, СЕД, головне завдання яких полягає в 
управлінні документами, є базовою складовою електронного уряду й електронного урядування.

У 2003 році Кабінет Міністрів України прийняв Постанову щодо створення електронної інформаційної системи «Електронний Уряд» [24]. Минуло вже 10 років 3 того часу, проте, не зважаючи на всі зусилля, в Україні, на жаль, поки «паперовий уряд» перемагає «електронний». Про це красномовно свідчить щорічний огляд електронних урядів E-Government Survey 2012 [22], де світовий індекс розвитку електронного уряду визначався для 190 держав, а показники оцінювалися за трьома групами параметрів: рівень розвитку онлайн-сервісів, рівень розвитку телекомунікаційної інфраструктури, індекс людського капіталу. До п’ятірки світових лідерів розвитку електронного уряду увійшли: Південна Корея, Нідерланди, Велика Британія, Данія та США. Російська Федерація піднялася на 27 місце, суттєво покращивши свої показники (59 місце в 2010 році), а Україна опустилася на 68 з 54 місце у 2010 році (див. рис. 1), поступившись, окрім Росії, іншим країнам СНД: Білорусі, Естонії, Казахстану, Вірменії та Молдові [28]. За індексом E-готовності (Government realiness) Україна посідає 122 місце, а за індексом Використання урядом IKT (Government usage) - 75 місце з 138 країн.

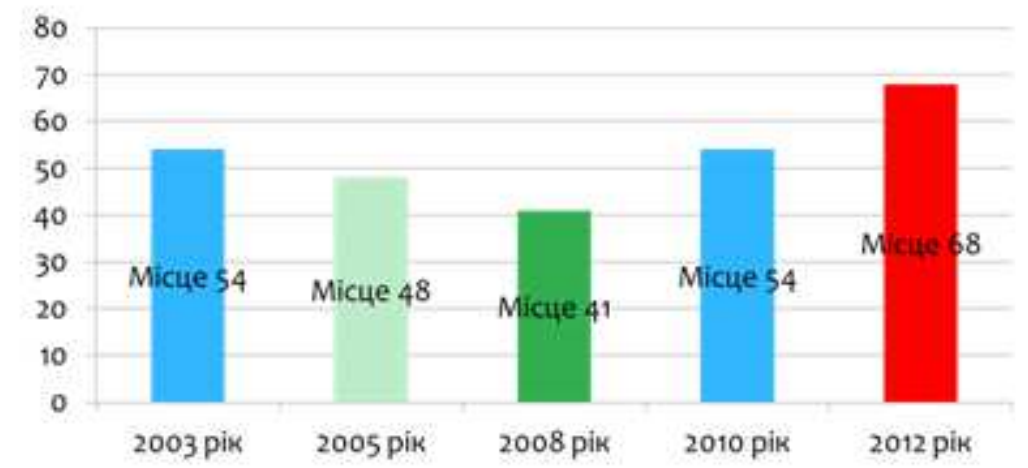

Рис. 1. Динаміка готовності Украӥни до електронного уряду

На таке відставання впливають різні політичні, економічні, організаційні, технологічні чинники. Зокрема, недостатня ефективність впровадження СЕД в діяльності державних органів, центральних органів виконавчої влади, органів місцевого самоуправління i, як наслідок, відсутність електронної взаємодії між ними. Це повною мірою стосується державних наукових установ.

Постановка проблеми. Державні наукові установи в Україні входять до складу Національної академії наук України і галузевих академій наук (Академія аграрних наук, Академія медичних наук, Національна академія педагогічних наук, Академія правових наук) (далі Академія), які належать до Центральних органів виконавчої влади. Відповідно їх діяльність, що регламентується Законом «Про наукову і науково-технічну діяльність» [13], повинна забезпечувати виконання Закону «Про електронні документи та електронний документообіг» [12]. На практиці це означає необхідність впровадження СЕД, з одного боку, як інструменту електронної взаємодії Академії з державними органами та органами виконавчої влади, а з другого, засобом менеджменту наукових досліджень на рівні Академії та підвідомчих наукових установ. Суб'єктами взаємодії Академії з державними органами й органами виконавчої влади є працівники апарату Президії Академії та апарату управління підвідомчих наукових установ Академії, а суб' єктами менеджменту наукових досліджень - учені секретарі відділень Академії, працівники апарату Президії Академії, учені секретарі, бухгалтери, 
працівники відділу кадрів, наукові керівники НДР підвідомчих наукових установ Академії. Розгортання робіт щодо впровадження СЕД в Академії як корпоративної системи є доцільним тільки тоді, коли реалізовані в ній бізнес-процеси будуть охоплювати спектр діяльності по роботі з документами всіх зазначених суб'єктів і забезпечувати такі умови і засоби, що ефективність діяльності кожного 3 них буде значно більшою, ніж за сьогоднішнього «паперового документообігу», коли роль друкарських машинок, як правило, виконує персональний комп'ютер зі встановленим MS Office-ом, підключений до локальної мережі з доступом до мережі Інтернет.

Відомо, що проблема ефективності впровадження будь-якої інформаційної системи (IC), у тому числі СЕД, у першу чергу залежить від показників іїі якості, що мають відповідати стандартам (ISO 9126:1-4, ISO 14598-1-6:1998-2000) [9-11]. Ці стандарти категоризують атрибути якості системи за 6 характеристиками: функціональні можливості, надійність, практичність, ефективність, супроводжуваність, мобільність. Характеристики поділяються на субхарактеристики, які оцінюються за допомогою внутрішніх або зовнішніх метрик [23]. Виходячи 3 принципових можливостей їх вимірювання, усі характеристики об'єднуються в три групи: категорійно-описові, кількісні та якісні. Отже, існує формалізований апарат, що дозволяє оцінювати якість СЕД і прогнозувати ефективність її впровадження.

Відповідність СЕД стандарту якості інформаційної системи $\epsilon$ необхідною, але недостатньою умовою ефективності ії впровадження, оскільки процес упровадження здійснюється людьми, і цей чинник суттєво впливає на кінцевий результат. Ролі осіб, які беруть участь у процесі впровадження, поділяються на дві категорії: розробники $i$ користувачі. У типовому життєвому циклі (ЖЦ) СЕД розробник забезпечує іiі необхідну якість, а користувач взаємодіє із системою, тобто користувач виконує певні діï, примушуючи систему виконувати їі роботу [7]. Отже, роль розробника як чинника ефективності впровадження СЕД опосередковано відображається у показниках іiі якості, у той час як роль користувача тільки пасивно відображається в якісній категорії IC Практичність через такі метрики, як зрозумілість, зручність використання, легкість опановування, привабливість.

На наш погляд, цього недостатньо, оскільки за умови належної якості системи роль користувача у забезпеченні ефективності впровадження на етапі випробування, введення в дію, експлуатації СЕД є визначальною. 3 огляду на це, важливого значення набуває проблема формування у користувача відповідних знань, умінь та мотивації щодо виконання своїх посадових обов'язків через відповідні бізнес-процеси СЕД у корпоративному середовищі Академії. Разом з тим, існує суперечність між моделлю бізнес-процесів, реалізованих у системі, і реальним документообігом, оскільки на стартових етапах ЖЦ - експертизи й аналізу вимог - розробникам, як правило, не вдається налагодити конструктивний діалог 3 потенційними користувачами, щоб сформувати максимально точні специфікації бізнес-процесів. Причина цього полягає не тільки у низькій мотивації потенційних користувачів до ведення діалогу, але в їхньому невмінні виокремити, формалізувати йі узагальнити особливості власних дій у процесі виконання своїх посадових обов'язків. Мова спілкування користувача і розробника різна. Проте, у процесі впровадження користувач, опановуючи термінологію, поняття, технологію виконання своїх виробничих завдань у середовищі СЕД, поступово навчається формулювати свої інтуїтивно виконувані дії й очевидні для нього, а не для розробника, необхідні умови. Це сприяє налагодженню конструктивного діалогу між користувачем і розробником, що надає розробнику можливість визначати вимоги щодо удосконалення i розвитку системи, що в результаті підвищує ефективність впровадження СЕД. Досягнення взаємодії користувача і розробника системи не виникає спонтанно, це має бути керований педагогічний процес на основі визначених 
цілей, завдань, умов, які визначимо як організаційно-педагогічні засади впровадження СЕД в наукових установах. Метою педагогічного процесу є формування готовності користувачів до впровадження СЕД. Оскільки користувачі - це працівники наукових установ, які мають отримувати знання і навички роботи в системі в процесі виконання своїх повсякденних завдань, то організація такого педагогічного процесу здійснюється на рівні неформальної освіти дорослих.

Отже, проблему розроблення організаційно-педагогічних засад впровадження СЕД в наукових установах необхідно вирішувати так, щоб забезпечити такі організаційно-педагогічні умови, що дозволять подолати вищевказану суперечність та сформувати готовність користувача до впровадження СЕД.

Стаття присвячена проблемі розроблення організаційно-педагогічних умов як складової організаційно-педагогічних засад впровадження СЕД в науковій установі.

Аналіз останніх досліджень і публікацій. У результаті аналізу енциклопедичних $[4 ; 16 ; 18 ; 19 ; 25 ; 30 ; 31]$, наукових [5-11; 15; 26], технічних [1;23; 29], педагогічних джерел $[2 ; 3 ; 20 ; 21]$ та нормативних документів [12-14; 22; 24; 27] автором виокремлено базові категорії дослідження і виділено основні поняття 3 їхніми означеннями, які подано за спаданням ступеня узагальненості, значущості та логічною послідовністю в контексті статті.

Документ (від лат. Documentum - зразок, свідчення, доказ) є матеріальним об'єктом, який містить інформацію у зафіксованому вигляді, спеціально призначеному для іiї передачі в часі й просторі [9]. Носієм інформації можуть бути глиняні таблички, папір, перфокарта, фотоплівка, магнітна стрічка, електронні файли тощо. Документи містять тексти на природній або формалізованій мові, зображення, звукову інформацію й інші. За змістом документи поділяються на науково-технічні (статті, книги, патенти, технічні звіти й описи), правові (постанови, укази, договори) й управлінські (накази, директиви). 3 1980-х - початку 1990-х років використовується розширене тлумачення, згідно з яким документом вважається будь-який матеріальний об'єкт, що переносить інформацію. Фахівці почали використовувати термін «документ» у контексті, пов'язаному 3 поняттями «інформація» i «комунікація», обмеживши його зміст атрибутивними елементами, а саме - наявністю інформації та матеріального носія.

У статті розглядається предметна область документообігу в наукових установах, тому далі буде використовуватися більш вузьке тлумачення терміну «документ» відповідно до його визначення в ГОСТ 16487-83 «Делопроизводство и архивное дело. Термины и определения», а саме: «документ - це матеріальний об' єкт з інформацією, що закріплена створеним людиною способом для передачі в часі і просторі». Таке тлумачення охоплює вхідні та вихідні документи СЕД. Відповідно до тлумачення Англо-українського тлумачного словника 3 обчислювальної техніки, Інтернету i програмування [25]: «документ в інформаційних технологіях — це будь-який об'єкт, розміщений у пам'яті комп'ютерної системи (складений документ, графічне зображення, презентація, відсканована копія паперового документа, оцифрований звуковий запис або цифровий відеозапис)».

Документ у вузькому тлумаченні - це діловий папір, що підтверджує будь-який факт або право на щось. Так, у державному праві документ тлумачать як письмовий акт, складений у передбаченій законом формі, що посвідчує юридичне значення певних фактів (народження особи, здобуття освіти, виробничий стаж тощо). До документів відносяться також різні посвідчення, що підтверджують особистість людини, його приналежність до певної організації або дозвіл займатися певною діяльністю.

Документи наукової установи включають як ділові папери, що охоплюють всі сторони її діяльності, так і наукову документацію (монографії, посібники, підручники, методичні рекомендації тощо). 
Документообіг - це рух документів в установі від моменту створення й одержання зі сторони до моменту передачі на зберігання до архіву.

Електронний документ - документ, інформація в якому зафіксована у вигляді електронних даних, включаючи обов'язкові реквізити документа. Електронний документ може бути створений, переданий, збережений і перетворений електронними засобами у візуальну форму. Візуальною формою подання електронного документа $\epsilon$ відображення даних, які він містить, електронними засобами або на папері у формі, придатній для сприймання його змісту людиною.

На сьогодні, коли застосовується електронний цифровий підпис (ЕЦП), набуло поширення визначення електронного документа як документа, створеного за допомогою засобів комп'ютерної обробки інформації, підписаного і збереженого на машинному носієві у вигляді файлу відповідного формату.

Електронний документообіг - сукупність процесів створення, оброблення, правлення, передавання, одержання, зберігання, використання та знищення електронних документів, які виконуються із застосуванням перевірки цілісності та у разі необхідності з підтвердженням факту одержання таких документів. Це єдиний механізм роботи з документами, представленими в електронному вигляді, з реалізацією концепції «безпаперового діловодства».

Інформачійна система (IC) - система, яка забезпечує збирання, зберігання та доступ користувачів до даних [25].

Широке розповсюдження має визначення IC, яке дав М. Р. Когаловський: «інформаційною системою називається комплекс, що включає обчислювальне i комунікаційне обладнання, програмне забезпечення, лінгвістичні засоби та інформаційні ресурси, а також системний персонал, який і забезпечує підтримку динамічної інформаційної моделі деякої частини реального світу для задоволення інформаційних потреб користувачів» [15].

Стандарт ISO / IEC 2382-1 дає таке визначення: «Інформаційна система система обробки інформації, що працює спільно з організаційними ресурсами, такими як люди, технічними засобами та фінансовими ресурсами, які забезпечують i розподіляють інформацію» [30].

Російський ГОСТ РВ 51987 визначає інформаційну систему як «автоматизовану систему, результатом функціонування якої є представлення вихідної інформації для подальшого використання».

У статті використовується визначення IC як організаційно-технічної системи для збереження та обробки інформації з метою забезпечення інформаційних потреб користувачів.

Система електронного документообігу (СЕД) - інформаційна система, що супроводжує процес управління роботою ієрархічної організації з метою забезпечення виконання цією організацією своїх функцій. Наразі передбачається, що процес управління спирається на документи, які людина може читати. Такі документи містять інструкції для співробітників організації, необхідні для виконання їхніх завдань.

У статті використовується визначення СЕД як інформаційної системи, що забезпечує процес створення, управління доступом i поширення електронних документів у комп'ютерних мережах, а також забезпечує групову роботу з документами i контроль над потоками документів в організації. Водночас передбачається, що реалізація СЕД здійснюється на базі веб-технологій у вигляді веб-порталу, а користувач працює із СЕД за допомогою стандартних веб-браузерів.

Життєвий циикл (ЖЦ) програмних систем - базове поняття програмної інженерії [1] для визначення схеми послідовності виконання робіт із проектування програмної системи. Різновиди діяльності, що визначають процеси ЖЦ програмної системи, 
зафіксовано у міжнародному стандарті ISO/IEC 12207:2008: System and software engineering - Software life cycle processes. Оскільки ядром IC і СЕД, що належить до класу IC, є програмна система, то поняття ЖЦ в контексті статті будемо вживати як визначення схеми послідовності виконання робіт з упровадження СЕД, починаючи 3 моменту прийняття рішення про необхідність її впровадження, побудови і закінчуючи моментом іiі повного вилучення з експлуатації. Оскільки це поняття $є$ ключовим для дослідження, то докладніше воно розглянуто у розділі 3.

Розробник СЕД. В ІТ-технологіях термін «розробник» визначає, як правило, особу, яка розробляє програмне забезпечення. У дослідженні термін «розробник СЕД» трактується як визначення кола осіб, що здійснюють всі етапи впровадження СЕД від формулювання цілей і завдань до навчання користувачів.

Користувач СЕД. Як зазначалося вище, користувач взаємодіє із системою 3 метою отримання певних результатів своїх завдань, виконаних системою. У дослідженні термін «користувач СЕД» описує співробітників наукових установ, керівництва і апарату Президії Академії, зареєстрованих в базі користувачів СЕД, які після авторизації й аутентифікації отримують доступ до документів і дозволи на операції з документами відповідно до політики прав у системі. Політика прав СЕД описує правила для рольових груп користувачів. Ролі об'єднують співробітників згідно їхніх посадових обов'язків і видів діяльності, наприклад, бухгалтер, співробітник відділу кадрів, науковий керівник НДР тощо. Конкретні співробітники, включаються в рольові групи відповідними розпорядчими документами як відповідальні особи за інформаційне забезпечення СЕД по тих документах, формування та обробка яких $\epsilon$ завданням рольової групи.

Упровадження - це насамперед суспільно організована і закріплена наявними та такими, що утверджуються в дійсності, новими інституційними формами, діяльність людей, покликана опредметнити їхні знання [32].

Російський учений В. Рассохін, аналізуючи свого часу управлінські та правові засади механізму впровадження досягнень науки в практику, пов'язав поняття впровадження 3 природою суперечності між наукою і практикою: «впровадження $\epsilon$ розв'язанням об'єктивної суперечності між наукою і виробництвом шляхом його перетворення у внутрішню суперечність власне виробництва» $[5,26]$.

Упровадження $є$ певним чином організованою діяльністю суб'єктів. Як засіб здійснення діяльності та функціонування виробничих відносин упровадження розгортається у функціях, які воно виконує, забезпечуючи спільну, асоційовану діяльність людей. Попри це, йому внутрішньо притаманна наявність об'єктивного становища людей у сфері діяльності з упровадження певних аспектів цієї діяльності, які формуються внаслідок такого впровадження. Йому також властива формалізована зумовленість людей один одним в організаційних межах упровадження.

Стосовно впливу на користувачів, упровадження СЕД виявляється озброєнням їх певною методикою, системою засобів, які полегшують виконання ними функціональних обов'язків і дозволяють стабільно досягати більш високих показників у роботі [26].

Організаційно-педагогічні засади. Великий тлумачний словник сучасної української мови визначає термін «засади» так: «1) основа чогось, те головне, на чому грунтується, базується що-небудь; 2) вихідне, головне положення, принципи, основа світогляду; 3) спосіб, метод здійснення чого-небудь» [4, с. 325]. Виходячи з тлумачення терміну «засади» як «вихідне, головне положення, принципи, основа світогляду» визначимо організаційно-педагогічні засади впровадження СЕД як основні положення організації впровадження разом $з$ педагогічними основами та принципами навчання користувачів СЕД. 
Організаційно-педагогічні умови. Успішність функціонування будь-якої системи безпосередньо залежить від точності дотримання певних умов.

Незважаючи на те, що предметом значної кількості педагогічних досліджень виступають педагогічні умови реалізації певних процесів, у сучасній науці $є$ певні розбіжності в тлумаченні самого поняття «педагогічна умова».

Перш ніж з'ясувати педагогічні умови, які впливають на процес формування готовності до використання інформаційно-комунікаційних технологій, у тому числі готовності користувачів до впровадження СЕД, необхідно чітко визначити поняття «умова».

У довідковій літературі надаються різні тлумачення поняття «умова», які мають багато спільного. Так, у «Філософському енциклопедичному словнику» зазначено: «умова - філософська категорія, в якій відображаються універсальні відношення речі до тих факторів, завдяки яким вона виникає та існує. Завдяки наявності відповідних умов властивості речей переходять 3 можливості в дійсність» $[31,482]$.

3 точки зору філософії, умова тлумачиться як фактор (латинське factor чинник), тобто рушійна сила, причина будь-якого процесу. Як філософська категорія поняття «умова» відображає універсальні стосунки між суб'єктами спілкування. За межами діяльності ці стосунки не можуть перетворитися на нову дійсність. Для цього потрібна причина. Тому причинність виконує функцію активного діяльнісного чинника. Саме він із матеріалу умов забезпечує продукування нової дійсності як кінцевого результату.

У психології «умову» розуміють як сукупність явищ зовнішнього і внутрішнього середовища, що ймовірно впливають на розвиток конкретного психічного явища; до того ж це явище опосередковується активністю особистості, групою людей.

Тлумачний словник С. Ожегова $[19,746]$ визначає умову як вимогу, що ставиться однією зі сторін, які домовляються; як усну чи письмову згоду про що-небудь; як правила, що встановлені в будь-якій сфері життя, діяльності; як обставини, за яких відбувається чи залежить що-небудь.

Науковці спеціально визначають термін «педагогічна умова» як певну обставину чи обстановку, яка впливає (прискорює чи гальмує) на формування і розвиток педагогічних явищ, процесів, систем, якостей особистості $[16,97]$.

Аналіз науково-педагогічної літератури 3 цього питання дає підставу дійти висновку, що багато вчених досліджували проблему визначення поняття «педагогічні умови» стосовно того чи іншого виду діяльності.

А. М. Алексюк, А. А. Аюрзанайн, П. І. Підкасистий під педагогічними умовами розуміють чинники, що впливають на процес досягнення мети, при цьому поділяють їх на: а) зовнішні: позитивні відносини викладача і студента; об'єктивність оцінки навчального процесу; місце навчання, приміщення, клімат тощо; б) внутрішні (індивідуальні): індивідуальні властивості студентів (стан здоров'я, властивості характеру, досвід, уміння, навички, мотивація тощо) [21].

Педагогічними умовами вважають обставини, що сприяють розвитку чи гальмуванню навчально-виховного процесу, їх визначають як комплекс засобів, наявних у навчального закладу для ефективного здійснення навчально-виховного процесу. На думку О. Бражнич, педагогічні умови є сукупністю об'єктивних можливостей змісту, методів, організаційних форм і матеріальних можливостей здійснення педагогічного процесу, що забезпечує успішне досягнення поставленої мети [3].

Умова - існуючий компонент комплексу об’ єктів (речей, їх станів, взаємодій), 3 наявності якого з необхідністю випливає існування даного явища. Весь цей комплекс, у цілому, називають достатніми умовами явища. Якщо з усіх можливих наборів умов 
відібрати загальні, одержуємо необхідні умови, тобто ті, що наявні кожного разу, коли має місце дане явище. Повний набір необхідних умов, з якого неможливо виключити жодного компонента, не порушивши обумовленості, називають необхідним і достатнім.

Визначення поняття «умови» в педагогіці передусім пов'язане $з$ педагогічним осмисленням цієї категорії. Досить широке поняття «умова» використовується в дидактиці для характеристики цілісного педагогічного процесу, окремих його сторін і складових частин. На думку В. Андрєєва, педагогічні умови $є$ результатом цілеспрямованого відбору, конструювання й застосування елементів змісту, методів, а також організаційних форм навчання для досягнення дидактичних цілей [2].

Організачійно-педагогічні умови є різновидом педагогічних умов, які залежать від особливостей організації навчально-виховного процесу. Б. Г. Чижевський вказує, що організаційно-педагогічні умови відображають «функціональну залежність суттєвих компонентів педагогічного явища від комплексу об'єктів (речей, їх станів, процесів, взаємодій) у різних проявах» [33, 82]. Механізми педагогічної організації, які покладено в основу забезпечення організаційно-педагогічних умов, охоплюють усі рівні й сфери взаємодії між викладачами, студентами та іншими суб'єктами освітнього процесу, виконують інтегральну функцію й забезпечують взаємозв'язки 3 громадськими об'єднаннями та іншими соціальними структурами. Ці механізми створюють передумови участі студентів у суспільних відносинах через засвоєння ідей, вимог, норм і цінностей, що панують в освітньому закладі.

Готовністю до використання IKT є інтегрована якість особистості, яка надає можливість ставити цілі, знаходити засоби їх досягнення, здійснювати самоконтроль за власними діями в умовах застосування засобів IКТ.

Мотивація - система мотивів або стимулів, яка спонукає людину до конкретних форм діяльності чи поведінки. За В. Онушкіним та Є. Огарьовим мотивація навчальної діяльності дорослих є сукупністю зовнішніх мотивів, індивідуальних прагнень i раціональних доказів, які визначають прийняття аргументованого рішення про продовження навчання [20].

Мета статті. Метою статті є опис моделі життєвого циклу впровадження СЕД, побудованої на основі типової моделі ЖЦ СЕД і доповненої розробленою автором організаційно-педагогічною моделлю впровадження СЕД, які у сукупності визначають організаційно-педагогічні засади впровадження електронного документообігу в наукових установах.

\section{2. МЕТОДИ ДОСЛІДЖЕННЯ}

У процесі дослідження використано основні методи наукового пізнання:

теоретичні - 3 метою уточнення понятійно-термінологічного апарату проблеми дослідження, визначення нормативної бази, формування теоретичних засад дослідження, обгрунтування організаційно-педагогічної моделі впровадження СЕД шляхом вивчення, систематизації науково-методичної, технічної та педагогічної літератури з проблеми дослідження, законодавчої та нормативної документації з питань наукової діяльності, інформатизації, паперового й електронного документообігу, міжнародних і вітчизняних стандартів у галузі інформаційних технологій, технічної документації на комерційні СЕД провідних виробників; узагальнення вітчизняного i зарубіжного досвіду щодо впровадження СЕД; методи системного аналізу застосовано для аналізу вимог та проектних рішень СЕД на платформі MS SharePoint;

емпіричні - діагностичні (анкетування, наративне інтерв'ю) - для констатування стану готовності користувачів до впровадження СЕД; експериментальні (констатувальний та формувальний етапи педагогічного експерименту) 3 метою 
апробації розробленої моделі організаційно-педагогічних умов впровадження СЕД; статистичні - для кількісного та якісного аналізу готовності користувачів до впровадження СЕД на різних етапах ЖЦ СЕД з організаційно-педагогічною моделлю впровадження; метод моделювання - для створення моделі організаційнопедагогічних умов впровадження СЕД; спостереження за процесом і результатами впровадження СЕД в науковій установі з метою отримання даних щодо ефективності цього процесу, добору, розроблення та апробації програмного забезпечення, що удосконалює функціонал системи.

Оскільки СЕД є інформаційною системою, то вона належить до класу об'єктів комп'ютерної науки (Computer Science) [9]. Для проведення дослідження використовується апарат таких дисциплін комп'ютерної науки, як системна інженерія (Systems Engineering) - методи і принципи побудови систем обробки інформації, та програмна інженерія (Software Engineering) - методи проектування програмних i інформаційних систем. Парадигма проектування означає конструювання комп'ютерних систем для забезпечення автоматизації робіт у різних організаціях і доменах і включає такі загальні кроки для реалізації заданої проблеми: опис вимог; опис специфікацій системи; проектування і виконання системи; тестування й оцінка надійності системи. Для розробки організаційних засад упровадження СЕД в науковій установі використовується науковий апарат опису вимог парадигми комп'ютерної науки Проектування. Це сформульовані Глушковим В. М. [5] методи проектування АСУ, які значною мірою відповідають проектуванню СЕД, включають: системний підхід (аналіз системи управління, іiї структуризацію і виділення в системі цілей та критеріїв); метод декомпозиції для визначення функціональних ознак підсистем: керівників, кадрового забезпечення, діловодства, моніторингу діяльності, моделювання, метод додавання нових задач.

\section{3. РЕЗУЛЬТАТИ ДОСЛІДЖЕННЯ}

\section{1. Особливості впровадження СЕД у наукову установу}

Упровадження СЕД в державну наукову установу має низку особливостей, оскільки основним видом діяльності таких установ $є$ наукові дослідження. Проблема інформатизації наукових досліджень незалежно від їх предметної галузі пов'язана 3 організацією, плануванням, контролем і моніторингом їх виконання, тобто процесами менеджменту. Фінансування, діяльність i, відповідно, менеджмент такої системи в основному здійснюється 3 державного бюджету i регулюється державними нормативними документами. Це забезпечує структурованість документообігу і бізнеспроцесів, що супроводжують виконання наукових досліджень, що $є$ передумовою розгляду менеджменту наукової діяльності як головної проблеми їх інформатизації. Оскільки процеси менеджменту здійснюються за допомогою управління і групової роботи з різними типами документів, то інформатизацію наукової діяльності доцільно розглядати, у першу чергу, в контексті процесів і функціональності систем електронного документообігу. Питання впровадження СЕД пов'язане з організаційними i технологічними проблемами. Якщо для сучасної компанії або підприємства ефективність впровадження СЕД виражається прибутком і $є$ необхідною складовою їі діяльності, то для наукової організації нині це питання якісних і прогностичних оцінок, престижу. Це обумовлює шляхи вирішення технологічних проблем, які залежать, 3 одного боку, від фінансування, а з іншого, визначаються власне предметною галуззю. Завдання СЕД для сучасної компанії або підприємства розв'язані в багатьох системах, широко представлених на ринку. Але оскільки вартість готової платформи СЕД 
занадто велика, таке рішення прийнятне для великих компаній і підприємств (винятком $\epsilon$ отримання академічної ліцензії у певних компаній розробників). Іншим варіантом $\epsilon$ використання вже існуючих програмних платформ СЕД, налаштування яких для конкретної СЕД потребують менших матеріальних затрат. Проте, вони є ефективними лише для тих замовників, для яких завдання проектованої СЕД досить типові та зрозумілі розробникам. В іншому випадку етап попереднього обстеження може істотно збільшити вартість системи, але наразі не забезпечить адекватної ефективності. Тому у процесі створення інформаційної системи менеджменту наукових досліджень необхідно застосовувати компромісний підхід, а саме, використання програмної платформи, яка забезпечує базові функції СЕД, а також підтримує розвинені засоби розробки додатків.

У рамках Академії є підрозділи інформатизації, які відповідають за розробку та впровадження СЕД у державні наукові установи. Ці підрозділи в даному випадку виступають як розробники СЕД. Саме вони здійснюють розробку надбудов, що виконують необхідні функції, які відсутні на обраній платформі. Надання можливості розробникам визначати вимоги щодо вдосконалення та розвитку впроваджуваної СЕД базується на посиленні діалогу між ними та користувачем.

Як зазначено вище, досягнення такої взаємодії користувача і розробників системи має бути керованим педагогічним процесом, побудованим на основі цілей і завдань, визначених педагогічними умовами впровадження СЕД в наукових установах.

\section{2. Педагогічні умови впровадження СЕД в наукову установу}

Педагогічні умови впровадження СЕД у наукову установу виступають структурною оболонкою педагогічних технологій чи моделей, завдяки яким реалізуються їх компоненти. Тому педагогічні умови відтворюють структуру готовності користувачів інформаційної системи до діяльності в умовах впровадження СЕД і містять передбачені технологією формування готовності компоненти моделі або технології [6].

Т. Гуцан вважає, що реалізація педагогічних умов передбачає забезпечення організаційно-педагогічного супроводу підготовки користувачів, визначення форм i методів інформаційної підтримки процесу формування їх готовності до впровадження СЕД в умовах наукової установи [6].

Як зазначалося вище, оскільки користувачі - це працівники наукових установ, які мають отримувати знання і навички роботи в системі в процесі виконання своїх повсякденних завдань, то організація такого педагогічного процесу здійснюється на рівні неформальної освіти дорослих.

За Л. Сігаєвою неформальна освіта — це навчання, що організовується не в стінах навчальних закладів (наприклад, на виробництві, в клубах та ін.) і здійснюється не обов'язково професійними викладачами (наприклад, колегами по роботі), і яке, як правило, не завершується отриманням загальновизнаного документа про освіту. Така освіта відрізняється двома 3 перелічених вище параметрів, а саме: систематизованістю навчання і цілеспрямованою діяльністю тих, хто навчається [29].

Як зазначалося вище, педагогічні умови є складовою організаційно-педагогічних засад.

\section{3. Організаційно-педагогічні засади впровадження СЕД}

Виходячи з розглянутих вище педагогічних умов та особливостей упровадження СЕД у наукову установу, пропонуємо представляти структуру організаційнопедагогічних засади впровадження СЕД двома складовими (див. рис. 2): 
- організаційне забезпечення впровадження СЕД;

- організаційно-педагогічні умови впровадження СЕД.

Організаційне забезпечення впровадження СЕД передбачає:

- розроблення нормативно-правових актів щодо впровадження та функціонування СЕД;

- призначення розробників системи;

- формування груп майбутніх користувачів;

- технічне забезпечення всіх наукових установ, що беруть участь у впровадженні СЕД, необхідними засобами.

Організаційно-педагогічними умовами впровадження СЕД є:

- перевірка готовності користувачів до впровадження СЕД;

- створення позитивної мотивації у майбутніх користувачів;

- розробка методичного матеріалу;

- підготовка і проведення семінарів і тренінгів;

- формування умінь і навичок роботи із СЕД.

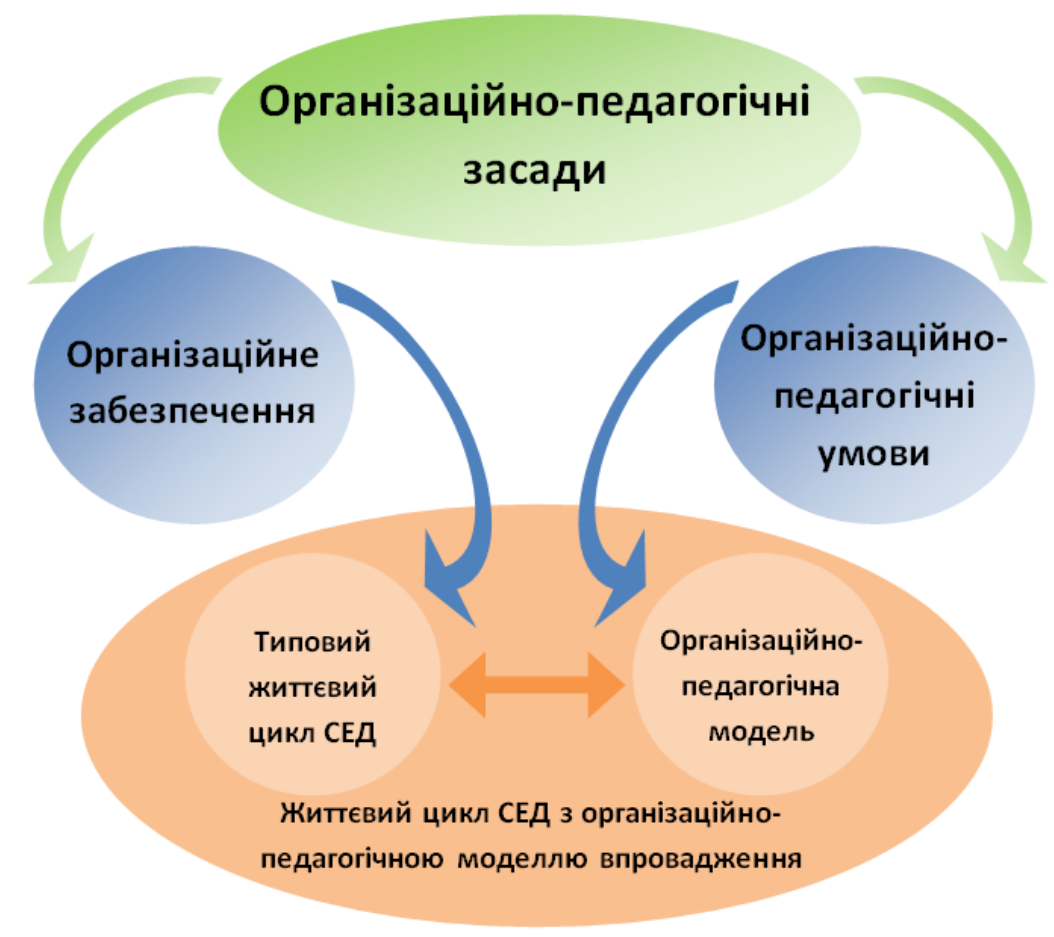

Рис. 2. Структура організачійно-педагогічних засад впровадження СЕД

В основі діяльності щодо створення і використання інформаційних систем лежить поняття життєвого циклу, що зазначене вище.

Модель життєвого циклу - структура, що складається з процесів, робіт та задач, які включають в себе розробку, експлуатацію і супровід програмного продукту; охоплює життя системи від визначення вимог до неї до припинення її використання.

Основними моделями життєвого циклу є каскадна, спіральна, ітераційна, або як іiі ще називають, еволюційна. При розробці i впровадженні сучасних СЕД використовується ітераційна модель ЖЦ [1].

Iтераційна модель передбачає доопрацювання повномасштабного зразка системи до рівня якості, що задовольняє кінцевих користувачів безпосередньо в процесі іiі експлуатації. Наразі реалізація системи починається з тих функцій, про які розробники мають досить чітке уявлення. Відомості стосовно інших функцій системи уточнюють 
уже після іiі часткової здачі в експлуатацію. У створенні складних інформаційних систем ітераційний підхід дає змогу на початку розробки зосередитися на досягненні високих експлуатаційних характеристик, таких як надійність, мобільність, модифікованість тощо.

\section{СЕД \\ 3.4. Життсвий цикл 3 організаційно-педагогічною моделлю впровадження}

Типовий життєвий цикл СЕД починається 3 експертизи й аналізу вимог до майбутньої системи. Під час аналізу вимог виявляються і встановлюються обмеження на функції і систему у цілому.

Формування вимог здійснюється залежно від документів, що циркулюють в організації, та з'ясовуються певні деталі вимог до системи в спілкуванні 3 співробітниками організації.

Після формування вимог складається технічне завдання i починається проектування системи, що передбачає декілька етапів. Спочатку на основі сформованих вимог обирається платформа, на базі якої відбуватиметься розробка системи. На цьому етапі вирішується, чи буде система розроблятись на основі вже готового рішення, або «з нуля». Після обрання платформи для створення системи розробляється інформаційна модель даних системи і вже за цією моделлю будується система.

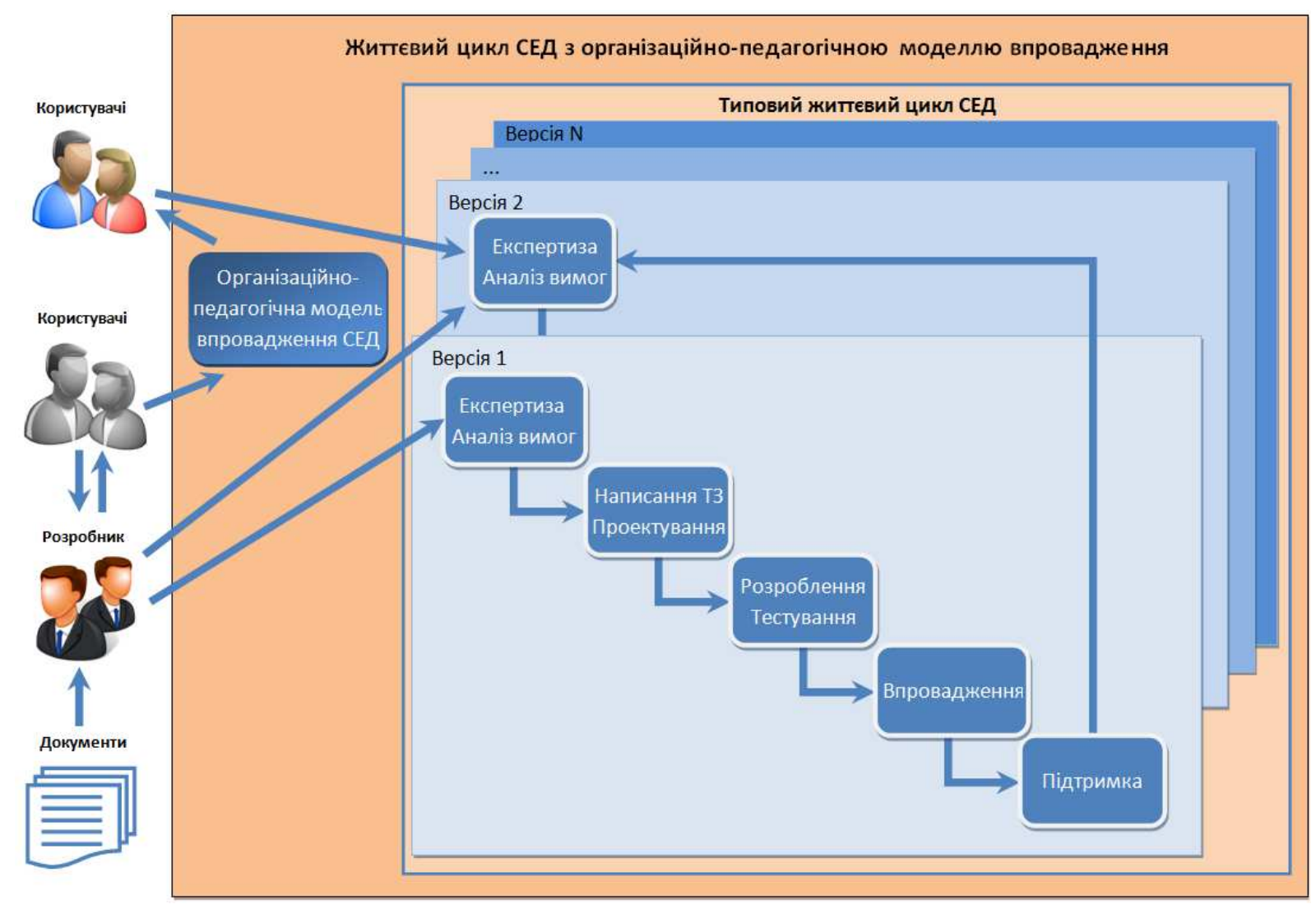

Рис. 3. Життєвий ичикл СЕД з організаиійно-педагогічною моделлю впровадження

Для початку створюється пілотна версія системи і здійснюється ії впровадження в невеликий структурний підрозділ організації. Система проходить валідацію та верифікацію щодо вимог, які були сформовані на початковій стадії проектування. При 
цьому виявляються недоліки інформаційної моделі даних і вносяться доповнення у вимоги до системи в цілому.

Виявлені недоліки оперативно виправляються, і система переходить на стадію тестування і налагодження. На цій стадії система налагоджується і тестується на наявність технічних помилок в ії описі, після виявлення та виправлення яких система впроваджується для решти структурних підрозділів організації, а життєвий цикл СЕД переходить до чергової ітерації.

У наступних версіях система доповнюється новим функціоналом або змінюється вже існуючий.

Проте недоліком типового ЖЦ СЕД $\epsilon$ неспроможність користувачів сформулювати вимоги та завдання, яким СЕД має відповідати та виконувати, з огляду на недостатній рівень готовності до впровадження IКТ.

Для підвищення рівня готовності користувачів системи до впровадження СЕД до ЖЦ СЕД було включено організаційно-педагогічну модель (ОПМ) впровадження СЕД. Після проходження навчання за ОПМ користувачі здатні сформулювати свої вимоги та пропозиції до СЕД та ОПМ впровадження СЕД.

\section{5. Організаційно-педагогічна модель впровадження СЕД}

Для формування та підвищення рівня готовності до впровадження СЕД у користувачів автором було розроблено ОПМ впровадження СЕД (див. рис. 4).

\subsection{1. Опис організаційно-педагогічної моделі впровадження СЕД}

Метою застосування моделі $€$ підвищення готовності користувачів до впровадження СЕД, яка включає в себе 3 компоненти: інформаційний, операційний, мотиваційний.

Інформаційний компонент характеризується наявністю сформованої інформаційної культури, володіння основами знань роботи з комп'ютером і методами застосування комп’ютера та IT у своїй професійній діяльності.

Операційний компонент передбачає сформованість системи знань, умінь та навичок використання IКТ для розв'язання повсякденних професійних завдань.

Мотиваційний компонент включає наявність стійкої позитивної мотивації, інтересу до використання ІКТ, особистісно значущого сенсу застосування IКТ, бажання постійно підвищувати свій рівень використання IКТ у професійній діяльності.

Педагогічними умовами до застосування ОПМ визначено:

- створення позитивної мотивації;

- розробку методичного матеріалу;

- формування умінь і навичок роботи із СЕД.

ОПМ впровадження СЕД включає 5 етапів:

- організаційно-підготовчий;

- мотиваційно-аналітичний;

- організаційно-настановчий;

- діяльнісно-корекційний;

- результативно-аналітичний.

На організаційно-підготовчому етапі здійснюється початкова діяльність стосовно процесу впровадження. Для цього на рівні наукової установи проводиться розробка та затвердження нормативних актів щодо впровадження, призначаються і формуються групи користувачів системою та здійснюється їх реєстрація у системі. 
У ході мотиваційно-аналітичного етапу визначається початкова готовність користувачів до впровадження СЕД через попереднє анкетування та інтерв’ювання.

\section{Мета: формування готовності користувачів до впровадження СЕД}

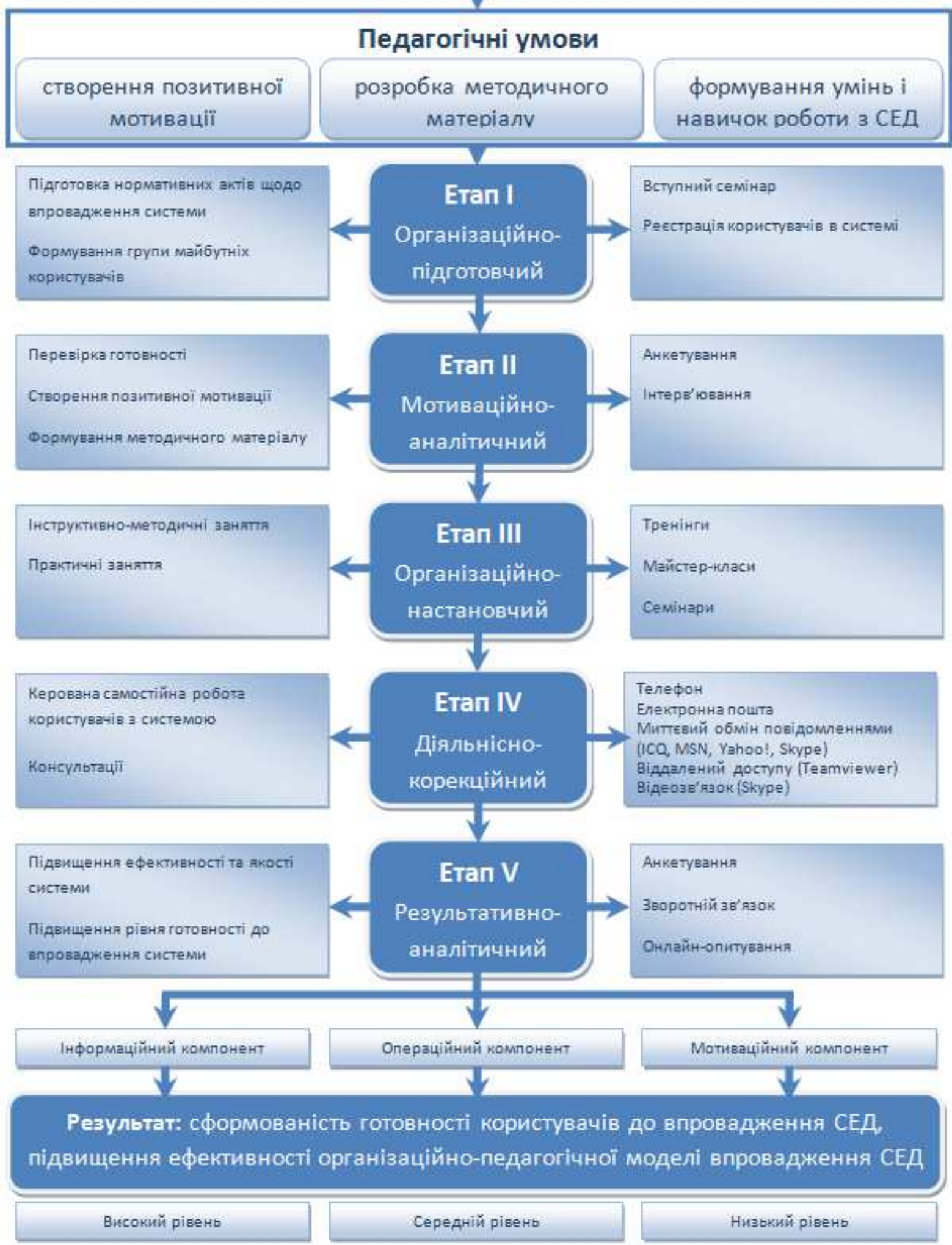

Рис. 4. Організащійно-педагогічна модель впровадження СЕД 
Оскільки мотивація є першим кроком будь-якого навчального процесу, то на цьому етапі важливим $\epsilon$ створення умов для формування внутрішньої позитивної мотивації у користувачів, спрямованості їх навчання до пізнавальної діяльності.

Організаційно-настановчий етап передбачає інструктивно-методичні заняття для початкової підготовки користувачів до роботи із СЕД. Відповідно до цього проводяться семінари, тренінги, майстер-класи для більш грунтовного знайомства із системою.

Під час діяльнісно-корекційного етапу користувачі працюють із системою самостійно, використовуючи методичний матеріал. У разі потреби під час роботи із системою користувачі отримують консультації від іiі розробників за допомогою електронної пошти, програм миттєвого обміну повідомленнями, програм віддаленого доступу, телефоном.

Результативно-аналітичний етап включає в себе обробку результатів навчання. Водночас здійснюється перевірка готовності користувачів до впровадження СЕД після проходження навчання, проводиться опитування користувачів щодо роботи системи $\mathrm{i}$ приймаються зауваження стосовно iï вдосконалення. За результатами опитування до системи формуються нові вимоги, за якими система доповнюється новим функціоналом, або змінюється вже існуючий.

\subsection{2. Апробація організаційно-педагогічної моделі впровадження СЕД}

Апробація ОПМ впровадження СЕД проводилася протягом експериментального етапу НДР «Науково-методичні засади інформатизації наукової і управлінської діяльності установ НАПН України на основі веб-технологій» (№ ДР 0109U002139) в 2009-2011pp. на порталі IC «Наукові дослідження» planning.edu-ua.net.

Методичні рекомендації щодо роботи з IC «Наукові дослідження», розроблені автором, розміщено в розділі «Допомога» порталу. Також автором розроблено систему контент типів для всіх типів документів, що супроводжують НДР.

За результатами опитування користувачів після проходження тренінгу було вдосконалено організаційно-педагогічну модель впровадження СЕД і доопрацьовано програмне забезпечення системи.

\subsection{3. Упроваджсення організаційно-педагогічної моделі впровадження СЕД}

Згідно Постанови Загальних зборів НАПН України у 2012 році розпочато введення в дію IC «Наукові дослідження», що здійснюється 3 використанням ОПМ впровадження СЕД.

Автором підготовлено і проведено методологічний семінар на базі НАПН України, після завершення якого отримано відгуки щодо методичного забезпечення i вдосконалено організаційно-педагогічну модель. На основі цих відгуків сформовано нові вимоги до IC «Наукові дослідження», за якими розроблено програмні засоби первинного наповнення документів і папок, що значно полегшує роботу користувачів.

У рамках упровадження IC «Наукові дослідження» сформовано базу даних НДР по 5 відділеннях і 15 установах НАПН України, що розпочалися у 2013 році, ведеться обробка документів з НДР, що розпочинаються у 2014 році.

Отже, результати проведеного впровадження з використанням запропонованої організаційно-педагогічної моделі впровадження СЕД доводять, що ця модель сприяє формуванню в користувачів позитивної внутрішньої мотивації до пізнавальної діяльності, активного самонавчання, враховуючи при цьому їхні пізнавальноособистісні прагнення й очікування. 


\section{4. ВИСНОВКИ ТА ПЕРСПЕКТИВИ ПОДАЛЬШИХ ДОСЛІДЖЕНЬ}

У результаті проведеного дослідження розроблено організаційно-педагогічну модель впровадження СЕД, використання якої дозволило удосконалити програмні i методичні засоби IC «Наукові дослідження» і визначити напрямок іiї розвитку.

Подальший розвиток дослідження щодо організаційно-педагогічної моделі впровадження СЕД планується здійснити у межах НДР «Методологія та технологічне забезпечення інформаційної системи моніторингу впровадження наукових досліджень в НАПН України», що розпочнеться у 2015 році.

Представлену в статті організаційно-педагогічну модель доцільно використовувати під час упровадження СЕД в інших сферах діяльності як чинник, що покращує якість роботи користувачів із системою, i, як наслідок, підвищує ефективність впровадження в цілому.

\section{СПИСОК ВИКОРИСТАНИХ ДЖЕРЕЛ}

1. ISO/IEC 12207:2008: System and software engineering. - Software life cycle processes.

2. Андреев, В. И. Педагогика творческого саморазвития. Инновационный курс / В. И. Андреев. Книга 1. - Казань : Изд-во Казанского университета, 1996. - 568 с.

3. Бражнич О. Г. Педагогічні умови диференційованого навчання учнів загальноосвітньої школи : дис. канд. пед. наук / О. Г. Бражнич. — Кривий Ріг, 2001. — 238 с.

4. Великий тлумачний словник сучасної української мови / [уклад. і голов. ред. В. Т. Бусел]. - К. ; Ірпінь : ВТФ «Перун», 2001. - 1440 с.

5. Глушков В. М. Основы безбумажной информатики / В. М. Глушков. - М. : Наука. Главная редакция физико-математической литературы, $1982 .-552 \mathrm{c}$.

6. Гуцан Т. Г. Педагогічні умови формування готовності майбутніх вчителів економіки до профільного навчання старшокласників / Гуцан Т. Г. [Електронний ресурс]. - Режим доступу : http://intkonf.org/gutsan-tg-pedagogichni-umovi-formuvannya-gotovnosti-maybutnih-vchitelivekonomiki-do-profilnogo-navchannya-starshoklasnikiv/.

7. Д. Леффингуэлл. Принципы работы с требованиями к программному обеспечению. Унифицированный подход / Д. Леффингуэлл, Д. Уидриг. — М. : "Вильямс", 2002. — 446 с.

8. Давидова В. Д. Неформальна освіта дорослих у навчальних гуртках Швеції : монографія / В. Д. Давидова. - Сімферополь : «Таврида», 2010. - 192 с.

9. Задорожна Н. Т. Менеджмент документообігу в інформаційних системах освіти (для ВНЗ і ППО) : навчально-методичний посібник ДО / Н. Т. Задорожна, К. М. Лавріщева. - К. : КП Видавництво «Педагогічна думка», 2007. -220 с.

10. Задорожна Н. Т. Концепція керованого проектування інформаційних систем управлінської діяльності / Н. Т. Задорожна, К. Л. Валь // Проблемы программирования. - 2003. - № 2. C. $65-75$.

11. Задорожна Н. Т. Підхід до проектування інформаційних систем в органах державного управління / Н. Т. Задорожна // Искусственный интеллект. — 2002. — № 3. - С. 410-419.

12. Закон України «Про електронні документи та електронний документообіг» від 22.05.2003 № 851IV [Електронний ресурс]. — Режим доступу: http://zakon2.rada.gov.ua/laws/show/851-15.

13. Закон України «Про наукову i науково-технічну діяльність» від 13.12.1991 № 1977-XII [Електронний ресурс]. — Режим доступу : http://zakon1.rada.gov.ua/laws/show/1977-12.

14.Закон України «Про Національну програму інформатизації» від 04.02.1998 № 74/98-ВР [Електронний ресурс]. — Режим доступу : http://zakon1.rada.gov.ua/laws/show/74/98-вр.

15. Когаловский М. Р. Перспективные технологии информационных систем / М. Р. Когаловский. М. : ДМК Пресс; Компания АйТи, 2003. - 288 с.

16. Краткий психологический словарь / [сост. Л. А. Карпенко ; под ред. А. В. Петровского, М. Г. Ярошевского]. — Ростов н/Д : Феникс, 1998. — 512 с.

17. Латко Я. В. Стан та перспективи розвитку інформаційного суспільства : (2-й Кіровоградський соціально-економічний форум «Інформаційне суспільство і влада») [Електронний ресурс] / Я. В. Латко. — Режим доступу : http://kr-forum.org.ua/foto/upload/Latko.ppt.

18. Новий тлумачний словник української мови / [уклад. В. Яременко, О. Сліпушко]. — К. : «Аконіт», 2000. -4 т. 
19. Ожегов С. И. Словарь русского языка: Ок. 57000 слов / под ред. докт. филол. наук, проф. Н. Ю. Шведовой. - [15-е изд., стереотип.]. — М. : Рус. яз., 1984. — 816 с.

20. Онушкин В. Г. Мотивация учебной деятельности. / В. Г. Онушкин, Е. И. Огарев // Энциклопедия профессионального образования: в 3-х т. / руководитель авт. коллектива научный и литер. редактор С. Я. Батышев. - M. : Российская академия образования. Ассоциация «Профессиональное образование», 1999. - Т. 2. - С. 94.

21. Організація самостійної роботи студентів в умовах інтенсифікації навчання : навч. посіб. / [А. М. Алексюк, А. А. Аюрзанайн, П. І. Підкасистий, В. А. Козаков та ін.]. — К. : ІСДО, 1993. $336 \mathrm{c}$.

22. Отчет ОЭСР «Необходимость внедрения електронного правительства» (The E-Government Imperative) [Електронний ресурс]. — Режим доступу : http://open-gov.ru/2010/11/10/issledovanie/.

23. Показатели качества информационной системы [Електронний ресурс]. - Режим доступу : http://rudocs.exdat.com/docs/index-37113.html\#1616509. — Назва з екрану.

24. Постанова Кабінету Міністрів України від 24.02.2003 р. № 208 «Про затвердження заходів щодо створення електронної інформаційної системи “Електронний уряд”» [Електронний ресурс]. Режим доступу : http://zakon4.rada.gov.ua/laws/show/208-2003-п.

25. Прайдаков Е. М. Англо-український тлумачний словник з обчислювальної техніки, Інтернету i програмування / Е. М. Прайдаков, Л. А. Теплицький. — К. : СофтПрес, 2005. — 547 с.

26. Рассохин В. П. Механизм внедрения достижений науки: политика, управление, право / В. П. Рассохин. - М. : Наука, 1985. - 286 с.

27. Розпорядження Кабінету Міністрів України «Про затвердження плану заходів з виконання завдань, передбачених Законом України "Про Основні засади розвитку інформаційного суспільства в Україні на 2007-2015 роки”»: від 15 серп. 2007 р. № 653-р [Електронний ресурс]. Режим доступу : http/www.kmu.gov.ua.

28. Серенок А. О. Від електронного уряду до електронного урядування: компетентність державних службовців : (2-й Кіровоградський соціально-економічний форум «Інформаційне суспільство і влада») [Електронний ресурс] / А. О. Серенок. - Режим доступу : http://krforum.org.ua/foto/upload/serenok.ppt.

29. Сігаєва Л. С. Характеристика структури освіти дорослих в сучасній Україні / Л. С. Сігаєва // Вісник Житомирського державного університету. Педагогічні науки. - 2011. — № 59. - С. 39.

30. Термины и определения стандарта ISO/IEC 2382-1 [Електронний ресурс]. - Режим доступу : http://www.morepc.ru/informatisation/iso2381-1.html.

31. Философский энциклопедический словарь / [гл. редакция : Л. Ф. Ильичев, П. Н. Федосеев, С. М. Ковалев, В. Г. Панов]. - М. : Сов. энцикл., 1983. - 840 с.

32. Философский энциклопедический словарь. - М. : Советская энциклопедия, 1993. — 840 с.

33. Чижевський Б. Г. Організаційно-педагогічні умови становлення ліцеїв в Україні / Б. Г. Чижевський. - К. : Інститут педагогіки АПН України, 1996. - 249 с.

Матеріал надійшов до редакиї 05.08.2013 p.

\section{ОРГАНИЗАЦИОННО-ПЕДАГОГИЧЕСКИЕ ОСНОВЫ ВНЕДРЕНИЯ ЭЛЕКТРОННОГО ДОКУМЕНТООБОРОТА В НАУЧНЫХ УЧРЕЖДЕНИЯХ}

\section{Тукало Сергей Николаевич}

аспирант

Институт информационных технологий и средств обучения Национальной академии педагогических наук Украины, г. Киев, Украина

kolobox@bigmir.net

Аннотация. Рассматривается проблема внедрения системы электронного документооборота (СЭД) в научных учреждениях как фактор электронного управления в Украине. Освещены особенности внедрения СЭД в государственных научных учреждениях. Выделены два аспекта внедрения: внедрение электронного документооборота как информационной системы и формирование готовности пользователей к внедрению в педагогический процесс, организованный на уровне неформального образования взрослых. Описаны организационно-педагогические основы внедрения в виде организационного обеспечения и организационно-педагогических условий готовности пользователей к внедрению. Изложено разработанную автором организационно-педагогическую модель 
внедрения СЭД. Типовая модель жизненного цикла СЭД дополнена организационнопедагогической моделью внедрения.

Ключевые слова: система электронного документооборота; жизненный цикл; разработчик; пользователь; организационно-педагогические условия; модель; неформальное образование.

\title{
ORGANIZATIONAL AND PEDAGOGICAL BASIS OF THE INTRODUCTION OF ELECTRONIC DOCUMENT MANAGEMENT IN RESEARCH INSTITUTIONS
}

\author{
Serhiy M. Tukalo \\ post-graduate student \\ Institute of Information Technologies and Learning Tools of the NAPS of Ukraine, Kyiv, Ukraine \\ kolobox@bigmir.net
}

\begin{abstract}
This paper is devoted to the implementation of electronic document management $(E D M)$ in research institutions as a part of the e-government in Ukraine. Process of EDM implementation in state institutions is analysed. Two aspects of EDM implementation are emphasized: EDM implementation as information system and users' readiness to implement the EDM into pedagogical process organized at the non-formal level of the adult education. The organizational and pedagogical principles are considered as the organizational support and pedagogical conditions to form user's willingness to implement EDM. The organizational and pedagogical model for EDM implementation is proposed. The typical life cycle model of EDM is supplemented by organizational and pedagogical model for EDM implementation, proposed in the paper.
\end{abstract}

Keywords: document management system; life cycle; developer; user; organizational and pedagogical conditions; model; non-formal education.

\section{REFERENCES (TRANSLATED AND TRANSLITERATED)}

1. ISO/IEC 12207:2008: System and software engineering. — Software life cycle processes (in English)

2. Andreev V. I. Pedagogy of creative self-development. innovative course / V. I. Andreev. - Kniga 1. Kazan' : Izd-vo Kazanskogo universiteta, 1996. - 568 s. (in Russian)

3. Brazhny`ch O. G. Pedagogical conditions of differentiated instruction secondary school students: dy`s. kand. ped. nauk / O. G. Brazhny`ch. - Kry`vy`j Rig, 2001. — 238 s. (in Ukrainian)

4. Great Dictionary of the Ukrainian language / Uklad. i holov. red. V.T. Busel. - K. ; Irpin: VTF «Perun», 2001. - 1440 s. (in Ukrainian)

5. Glushkov V. M. Fundamentals of nonpaper Computer Science / V. M. Glushkov. - M. : Nauka. Glavnaja redakcija fiziko-matematicheskoj literatury, 1982. — 552 s. (in Ukrainian)

6. Guczan T. G. Pedagogical conditions of the training of future teachers of economics to high school specialized education [online] / T. G. Guczan. - Available from : http://intkonf.org/gutsan-tgpedagogichni-umovi-formuvannya-gotovnosti-maybutnih-vchiteliv-ekonomiki-do-profilnogonavchannya-starshoklasnikiv/. (in Ukrainian)

7. D. Leffingujell. How to work with software requirements. A unified approach / D. Leffingujell, D. Uidrig. - M. : "Vil'jams", 2002. - 446 s. (in Russian)

8. Davy`dova V. D. Informal adult education in educational circles Sweden: Monografiya / V. D. Davy`dova. - S. : «Tavry`da», 2010. — 192 s. (in Ukrainian)

9. Zadorozhna N. T. Document Management in the Information Systems Education (for high schools). / N. T. Zadorozhna, K. M. Lavrishcheva // Navchalno-metodychnyi posibnyk DO.: KP Vydavnytstvo «Pedahohichna dumka», 2007. - S. 220. (in Ukrainian)

10. Zadorozhna N. T. The concept of guided design of management information systems / N. T. Zadorozhna, K .L. Val // Problemy prohrammyrovanyia. 2003. — \#2. - S. 65-75. (in Ukrainian)

11. Zadorozhna N. T. The approach to the design of information systems in public administration / N. T. Zadorozhna // Yskusstvennыi yntellekt. — 2002. — \#3. — S. 410-419. (in Ukrainian)

12. The Law of Ukraine "On electronic documents and electronic document" from 22.05.2003 № 851-IV [online]. — Available from : http://zakon2.rada.gov.ua/laws/show/851-15. (in Ukrainian) 
13. The Law of Ukraine "On scientific and technical activities" from 13.12.1991 № 1977-XII [online]. Available from : http://zakon1.rada.gov.ua/laws/show/1977-12. (in Ukrainian)

14. The Law of Ukraine "On the National Program Information" from 04.02.1998 № 74/98-BP [online]. Available from : http://zakon1.rada.gov.ua/laws/show/74/98-вp. (in Ukrainian)

15. Kogalovskij M. R. Forward-looking information systems technology / M. R. Kogalovskij.- M. : DMK Press; Kompanija AjTi, 2003. - 288 s. (in Russian)

16. Brief psychological dictionary / [sost. L. A. Karpenko ; pod red. A. V. Petrovskogo, M. G. Jaroshevskogo]. — Rostov n/D : Feniks, 1998. — 512 s. (in Russian)

17. Latko Ya. V. Status and prospects of development of information society: (2-y Kirovohradskyi sotsialnoekonomichnyi forum «Informatsiine suspilstvo i vlada») [online] / Ya. V. Latko. — Available from : http://kr-forum.org.ua/foto/upload/Latko.ppt. (in Ukrainian)

18. New Dictionary of the Ukrainian language / uklad. V. Yaremenko, O. Slipushko. — K. : «Akonit», 2000 -4 t. (in Ukrainian)

19. Ozhegov S. I. Dictionary of Russian language: Ok. 57000 slov/ Pod red. dokt. filol. nauk, prof. N. Ju. Shvedovoj. - 15-e izd., stereotip. — M. : Rus. jaz., 1984. - 816 s. (in Russian)

20. Onushkin V. G. Motivation training activities. / V. G. Onushkin, E. I. Ogarev // Jenciklopedija professional'nogo obrazovanija: v 3-h t. / Rukovoditel' avt. kollektiva nauchnyj i liter. redaktor S. Ja. Batyshev. - M. : Rossijskaja akademija obrazovanija. Associacija «Professional'noe obrazovanie», 1999. - T. 2. - S. 94. (in Russian)

21. Organization of independent work of students in the intensification of training: navch. posib. / [A. M. Aleksiuk, A. A. Aiurzanain, P. I. Pidkasystyi, V. A. Kozakov ta in.]. — K. : ISDO, 1993. - 336 s. (in Ukrainian)

22. OECD report "The need for the introduction of E-Government" (The E-Government Imperative) [online]. - Available from : http://open-gov.ru/2010/11/10/issledovanie/. (in Russian)

23. Indicators of quality information system [online]. - Available from : http://rudocs.exdat.com/docs/index-37113.html\#1616509. — Nazva z ekranu. (in Russian)

24. Cabinet of Ministers of Ukraine from 24.02.2003, № 208 «On approval of the creation of an electronic information system" e-Government"» [online]. - Available from : http://zakon4.rada.gov.ua/laws/show/208-2003-п. (in Ukrainian)

25. Praidakov E. M. English-Ukrainian Dictionary of computing, Internet and Programming / E. M. Praidakov, L. A. Teplytskyi. - K. : SoftPres, 2005. - 547 s. (in Ukrainian)

26. Rassohin V. P. The mechanism of the introduction of science: policy, management, law / V. P. Rassohin. - M. : Nauka, 1985. — 286 s. (in Russian)

27. Cabinet of Ministers of Ukraine "On approval of a plan of tasks stipulated by the Law of Ukraine" On Fundamentals of Information Society in Ukraine in 2007-2015 "": from 15.08.2007 p. № 653-p [Online]. - Available from: http/www.kmu.gov.ua. (in Ukrainian)

28. Serenok A. O. From e-Government to e-Governance: competence of civil servants: (2-y Kirovohradskyi sotsialno-ekonomichnyi forum «Informatsiine suspilstvo i vlada») [online] / A. O. Serenok. — Available from : http://kr-forum.org.ua/foto/upload/serenok.ppt. (in Ukrainian)

29. Sihaieva L. Ye. Characteristic patterns of adult education in modern Ukraine / L. Ye. Sihaieva // Visnyk Zhytomyrskoho derzhavnoho universytetu. Pedahohichni nauky. — 2011. — \#59. — S. 39. (in Ukrainian)

30. Standard terms and definitions ISO/IEC 2382-1 [online]. - Available from : http://www.morepc.ru/informatisation/iso2381-1.html. (in Russian)

31. Encyclopedic Dictionary of Philosophy / [gl. redakcija : L. F. Il'ichev, P. N. Fedoseev, S. M. Kovalev, V. G. Panov]. - M. : Sov. jencikl., 1983. — 840 s. (in Russian)

32. Encyclopedic Dictionary of Philosophy. - M. : Sovetskaja jenciklopedija, 1993. - 840 s. (in Russian)

33. Chyzhevskyi B. H. Organizational and pedagogical conditions of formation of schools in Ukraine / B. H. Chyzhevskyi. - K. : Instytut pedahohiky APN Ukrainy, 1996. - 249 s. (in Ukrainian) 